\title{
Effects of Exchange Rate Volatility on Stock Market Return Volatility: Evidence from an Emerging Market
}

\author{
Perera H. A. P. K. \\ Department of Finance, Faculty of Management \& Finance, University of Colombo, P.O. Box 1490, Colombo 03, Sri Lanka.
}

\begin{abstract}
The purpose of this study is to empirically investigate the effects of exchange rate volatility on stock market return volatility from an emerging market's perspective.This study utilizes daily time series data for All Share Price Index (ASPI) returns of Colombo Stock Exchange (CSE) and exchange rates over a period of six years from January 2010 to December 2015. Further, the study utilizes the Generalized Autoregressive Conditional Heteroscedasticity (GARCH) estimation modelin order to identify the impact of exchange rate volatility on stock market return volatility. The empirical results of the study reveal that the volatility of Euro exchange rate has a positive and significant impact on ASPI return volatility whilst the volatility of US Dollars and British Pounds exchange rates are found to be negative and insignificant. Overall, the findings of the study highlight that the exchange rate volatility is another determinant of stock market return volatility where due consideration should be given in making capital market investment decisions.
\end{abstract}

Keywords: Stock market return volatility, Exchange rate volatility, GARCH, Colombo Stock Exchange

\section{Introduction}

In the modern world the globalization has created numerous global links throughout the world resulted in a marked growth in interactions among international financial markets (Karunanayake, Valadkhani\& O'Brien, 2009). As a result of this heavy interlinks among global financial markets economies are highly vulnerable for the changes occurred in the international financial markets (Subair, 2009). Therefore, it has become very much critical to investigate these financial market inter links. Furthermore, a boost in an economic growth can be expected through a well-functioning financial system where the stock market plays a vital role in achievingsuch economic growth (Muktadir-Al-Mukit, 2012).

Jegajeevan(2012), depicted that the volatility in stock returns more frequently used as a measure of risk so that such volatilities in stock returns widely use in areas such as hedging, asset pricing and portfolio selection. Moreover, Pieris and Pieris (2011), demonstrated that people tend to believe volatility as a signal of market disruption where the capital markets are not functioning at the expected level together with presence of mispriced securities. Thus, the volatility in the stock returns is perceived as critical so that understanding the volatility of the stock returns has long been a topic of considerable interest.

Due to recent changes in the global financial markets, exchange rates have started to fluctuate violently so that it has created both negative and positive repercussions to countries throughout the world. Joseph (2002) noted that the exchange rate directly affects on international competitiveness of the firms based on the price levels of inputs and outputs of such firms. However, the empirical evidence on the influence of exchange rate volatility on the volatility of stock returns is inconsistent (Mishra, 2004; Solnik, 1987). Further, being an emerging market country,Sri Lanka has confronted several changes to its exchange rate regime time to time where strong fluctuations in the exchange rates have occurred due to various consequences resulted not only from internal environment but also from external environment as well. Thus, in this paper the author attempts to empirically investigate the impact of exchange rate volatility on stock market return volatility from an emerging country's perspective by using both standard Ordinary Least Squares (OLS) and Generalized Autoregressive Conditional Heteroscedasticity(GARCH) models whereas Karoui (2006), depicted that the emerging market countries are tightly linked with major currencies in the world such as US dollars, Euros and British Pounds. Furthermore, the contribution of this paper to the existing literature is two-fold. Firstly, as per author's best knowledge, this is the first study that has conducted to capture the impact of exchange rate volatility on stock market return volatility in Sri Lanka. Since, this study is based on daily data so that it provides stronger evidence on sensitivity of changes in share market returns to that of the changes in the exchange rates. Secondly, in order to enhance the reliability of the empirical results and the effectiveness of the estimated parameters, this study utilizes two different econometric approaches, standard OLS and GARCH model.

The remainder of the paper is organized as follows; Section 2 presents the literature review, Section 3 elaborates the date and methodology, data analysis and discussion of results presented in Section 4 while Section 5 provides the conclusions.

\section{Literature Review}

The impact of exchange rate volatility on share market volatility has become quite important after the 1997 financial crisis in Asian countries where financial literature identifies a fundamental relationship between exchange rate and stock market volatilities. Agarwal, Srivastav and Srivastav (2010), reported that theoretically based on the multinational characteristics of a firm, exchange rate movements affect the foreign operations of the firms so that it will directly impact on total profits of the firm and thereby the stock price of the firm. Further, Solnik (1987), Sercu (1980) and Adler and 


\section{International Journal of Science and Research (IJSR) \\ ISSN (Online): 2319-7064 \\ Index Copernicus Value (2013): 6.14 | Impact Factor (2014): 5.611}

Dumas (1983) demonstrated that risks created through the movements in exchange rate should be taken into consideration as a prime factor of equity return determination. Moreover, they further illustrated that the discount rate of firms will be directly affected through the developments in the currency market. Based on the empirical studies of Shapiro (1975), Levi (1994) and Marston (1998), it is precisely demonstrated that the competitiveness and the market values of the firms are directly affected by the exchange rate.

On the other hand, Adjasi and Biekpe (2005), reported that as per the stock oriented model, relative currency movements have a significant impact on the financially held assets so that this conjecture implies that currency movements may influence on the stock price volatility. Moreover, Branson and Handerson (1988), and Frankel (1983) through the portfolio balanced model, demonstrated that the connection between the movements of exchange rate and stock market has a negative relationship. They further depicted that this negative association between these two variables would be resulted at the macro level where domestic wealth falls as a result of fall in the stock prices and thereby a capital outflow would occur as a result of drop in the interest rates. Thus, it creates a reduction in demand for domestic money so that domestic currency would be depreciated. Despite the theoretical appealing on the association between exchange rate and stock market volatilities, early empirical studies on this discipline (Jorion, 1991) failed to construct valid evidence to support the relationship between exchange rate and stock market movements.

However, Maysumi and Koh (2000) through their empirical study demonstrated that interest rate and exchange rate should also be considered as determinants of stock prices. Further, Najan and Seifert (1992) reported that the absolute difference in the stock returns have positive impact on the exchange rate volatility. In addition to that, it is found that increase in aggregate domestic stock prices would have a positive long run effect on domestic currency value (Ajayi\&Mougoue 1996). Similarly, Aggarwal (1981) reported a positive association between exchange rate and stock market volatilities through his study on influence of exchange rates on US stock market prices.

Despite the existence of such positive association between exchange rate and share market volatilities literature also provides valid evidence for a negative association between these two variables as well. Sekmen (2011), using ARIMA models on stock returns for the US discovered that exchange rate volatility negatively affect stock returns. He further concluded that availability of hedging instruments could not lessen the negative impact of exchange rate volatility on the volume of trade. Olugbenga (2012) also depicted a significant negative association between stock market return and exchange rate in the long run by employing the Johansen cointegration test. Further, Ajayi and Mougoue (1996), reported that share prices have a negative short term effect on domestic currency value whilst Kim (2003), depicted that S\&P's common stock price negatively result with the exchange rate.
Thus, it is quite evident that the existing literature provides inconsistent conclusions regarding the influence of exchange rate volatility on share market volatility. Moreover, Alam and Taufique (2007), Morales (2008) admitted that further research in the area of impact of exchange rate volatility on share market volatility is required so that the Author attempts to address this requirement by providing some empirical evidence from an emerging market's perspective.

\section{Data and Methodology}

This paper empirically investigates the impact of exchange rate volatility on stock market return volatility. The sample of the study consists of daily market values of All Share Price Index (ASPI) of Colombo Stock Exchange (CSE) and the daily exchange rate values of US Dollar, Euro and British Pound for a period of six years from 05 January 2010 to 31 December 2015. The daily market values of ASPI were obtained from yahoo finance while the daily exchange rate values were obtained from www.quandl.com.

The data was then tested for stationarity by using Augmented Dickey-Fuller (ADF) test in order to avoid constructing spurious regressions which can be occurred due to the problem of unit root that presence when working with nonstationary time series data. In order to analyze the impact of exchange rate volatility on stock market volatility this paper first employs the OLS method where equation (1) specifies the model that is estimated with OLS.

$$
r_{t}=\beta_{0}+\beta_{1} U S D_{t}+\beta_{2} G B P_{t}+\beta_{3} E U R_{t}+\mu_{t}
$$

where $r_{t}$ is the daily stock returns of ASPI calculated by taking the natural logarithm of the daily closing price relative, i.e. $r_{t}=\ln \left(\mathrm{P}_{\mathrm{t}} / \mathrm{P}_{\mathrm{t}-1}\right) ; \beta_{0}$ is the intercept; $\mathrm{USD}_{\mathrm{t}}$ is the natural logarithm of daily exchange rate i.e. $\mathrm{USD}_{\mathrm{t}}=$ $\ln \left(\right.$ Dollar $_{t} /$ Dollar $\left._{t-1}\right)$; $\mathrm{GBP}_{t}$ is the natural logarithm of daily exchange rate i.e. $\mathrm{GBP}_{t}=\ln \left(\right.$ Pound $_{\mathrm{t}} /$ Pound $\left._{\mathrm{t}-1}\right) ; \mathrm{EUR}_{\mathrm{t}}$ is the natural logarithm of daily exchange rate i.e. $\mathrm{EUR}_{\mathrm{t}}=\ln \left(\mathrm{Euro}_{\mathrm{t}} /\right.$ Euro $\left._{\mathrm{t}-1}\right) ; \beta_{1}$ to $\beta_{3}$ specify the coefficients of the parameters; and $\mu_{t}$ is the white noise error term. The suitability of this estimated OLS model is then tested with the Autoregressive ConditionalHeteroscedasticity (ARCH) test.

Then the GARCH process, which was firstly introduced by Bollerslev (1986), employs to estimate the parameters where the GARCH $(1,1)$ process is specified as follows;

$$
\begin{aligned}
& r_{t}=\gamma_{0}+\gamma_{1} U S D_{t}+\gamma_{2} G B P_{t}+\gamma_{3} E U R_{t}+\varepsilon_{t} \\
& \sigma_{t}^{2}=\omega_{0}+\alpha_{1} \varepsilon_{t}^{2}+\alpha_{2} \sigma_{t}^{2}
\end{aligned}
$$

The equation (2) is the mean equation and the equation (3) is the variance equation where the parameters are defined same as the previous model; $\gamma_{0}$ is the intercept; $\gamma_{1}$ to $\gamma_{3}$ are the coefficients of the estimated parameters of the mean equation. $\sigma_{t}^{2}$ is the conditional variance where $\omega_{0}$ is the mean; $\alpha_{1} \varepsilon_{t}^{2}$ is the news about volatility from the previous period, measured as the lag of the squared residual from the mean equation which is defined as $\mathrm{ARCH}$ term; and $\alpha_{2} \sigma_{t}^{2}$ is the last period's forecast variance which is defined as the GARCH term. The GARCH specification requires that in the conditional variance equation, parameters $\omega_{0} . \alpha_{1}$, and $\alpha_{2}$ to be non-negative and the sum of $\alpha_{1}$ and $\alpha_{2}$ to be less than 


\section{International Journal of Science and Research (IJSR) \\ ISSN (Online): 2319-7064 \\ Index Copernicus Value (2013): 6.14 | Impact Factor (2014): 5.611}

one to secure the covariance stationarity of the conditional variance.

Finally, the equation (4) and equation (5) are estimated by using the GARCH $(1,1)$ model in order to capture the impact of exchange rate volatility on stock market return volatility.

$$
r_{t}=\emptyset_{0}+\varepsilon_{t}
$$

$$
\begin{aligned}
& \sigma_{t}^{2}=\varphi_{0}+\theta_{1} \varepsilon_{t}^{2}+\theta_{2} \sigma_{t}^{2}+\delta_{1} \operatorname{VolUSD}_{t}+\delta_{2} \operatorname{VOlGBP}_{t}+ \\
& \delta_{3} \text { VolEUR }
\end{aligned}
$$

where VolUSD Vis $_{t}$ the volatility values of US Dollars calculated through a GARCH $(1,1)$ process; $\operatorname{VolGBP}_{t}$ is the volatility values of British Pounds calculated through a GARCH $(1,1)$ process; VolEUR ${ }_{t}$ is the volatility values of Euros calculated through a GARCH $(1,1)$ process to capture impact of exchange rate volatilities on stock return volatilities.

\section{Data Analysis and Discussion}

\subsection{Descriptive Statistics and Stationarity}

The descriptive statistics of the study demonstrated in the Table 1 where the data was tested for the normality through JB test. The skewness should be 0 and kurtosis should equal to 3 in order to indicate that the variables are normally distributed where higher or lower kurtosis value indicates extreme leptokurtic or extreme platykurtic (Parkinson 1987). Based on the results obtained in Table 1 it is evident that the JB test has failed and all variables are deviated from normal distribution. Although, the results demonstrate positive skewness values for return, GBP, and EUR which are closer to zero while USD reports a positive skewness value of 1.96 , the kurtosis values of all variables are more than 3 indicating the presence of significant leptokurtic or fat tailed.

Table 1:Descriptive statistics

\begin{tabular}{|c|c|c|c|c|}
\hline & RETURN & USD & GBP & EUR \\
\hline Mean & 0.000473 & 0.00016 & 0.000101 & $-2.87 \mathrm{E}-05$ \\
\hline Median & 0.000247 & $8.78 \mathrm{E}-06$ & $7.77 \mathrm{E}-05$ & 0.000167 \\
\hline Std. Dev. & 0.007981 & 0.00208 & 0.003807 & 0.004427 \\
\hline Skewness & 0.109562 & 1.964176 & 0.174918 & 0.018353 \\
\hline Kurtosis & 7.602043 & 23.51616 & 5.323274 & 4.675069 \\
\hline Jarque-Bera & 1276.262 & 26235.24 & 331.8892 & 168.7831 \\
\hline Probability & 0.00000 & 0.00000 & 0.00000 & 0.00000 \\
\hline
\end{tabular}

On the other hand, the results of ADF test for stationarity are demonstrated in Table 2 where the results reject the null hypothesis of variable has a unit root in order to ensure that all variables are stationary all levels.

Table 2: ADF Test

\begin{tabular}{|l|l|l|c|}
\hline Variable & & t-Statistic & Prob. \\
\hline RETURN & ADF test statistic & -30.7653 & 0.00000 \\
\hline USD & ADF test statistic & -17.3915 & 0.00000 \\
\hline GBP & ADF test statistic & -17.3355 & 0.00000 \\
\hline EUR & ADF test statistic & -17.5727 & 0.00000 \\
\hline
\end{tabular}

\subsection{OLS estimation}

The Table 3 demonstrates the results of OLS estimation. As per the results, it depicts that only US dollar has a significant impact on the ASPI returns while British Pounds and Euros are found to be insignificant in determining the ASPI returns of CSE. Moreover, the evidence of the OLS estimation further reveals that both US dollars and Euros have a negative association with the ASPI returns whereas the nexus between British Pounds and ASPI returnsare found to be positive. However, the suitability of the regression OLS estimates is tested with the ARCH test. The results of the $\mathrm{ARCH}$ test are presented in the Table 4 where if the squared residuals of the equation (1) contain autocorrelation or heteroscedasticity, the null hypothesis would be rejected. Thus, the results precisely demonstrate that the null hypothesis would be rejected at $1 \%$ significant level indicating that classical OLS estimated coefficients are not effectively estimated so that inferences based on such coefficients are unreliable and unaccepted.

Table 3: OLS regression estimates Dependent Variable: RETURN

\begin{tabular}{|c|c|c|c|c|}
\hline \multicolumn{5}{|c|}{ Dependent Variable: RETURN } \\
\hline Variable & Coefficient & Std. Error & t-Statistic & Prob. \\
\hline C & 0.000516 & 0.00021 & 2.45419 & 0.0142 \\
\hline USD & -0.33463 & 0.114341 & -2.92656 & 0.0035 \\
\hline GBP & 0.091945 & 0.079649 & 1.154378 & 0.2485 \\
\hline EUR & -0.05582 & 0.063775 & -0.8753 & 0.3816 \\
\hline R-squared & 0.006795 & \multicolumn{4}{|c|}{ Adjusted R-squared } & 0.004724 \\
\hline Prob. (F-statistic) & 0.020213 & \multicolumn{4}{|c|}{ Durbin-Watson stat } & 1.598324 \\
\hline
\end{tabular}

Table 4:Heteroskedasticity Test: ARCH

\begin{tabular}{|c|c|c|c|}
\hline \multicolumn{4}{|c|}{ Heteroskedasticity Test: ARCH } \\
\hline F-statistic & 78.79528 & Prob. F(1,1440) & 0.00000 \\
\hline Obs*R-squared & 74.81113 & Prob. Chi-Square(1) & 0.00000 \\
\hline
\end{tabular}

\subsection{Estimation of return with GARCH $(1,1)$ model}

The results of the estimated GARCH $(1,1)$ parameters of the conditional return are depicted in Table 5 . In contrast to the OLS estimated output in Table 3 , the results of the mean equation of the GARCH $(1,1)$ model depict that USD has an insignificant impact on ASPI returns while GBP and EUR have a significant impact on ASPI returns. However, there is no significant deviation from the OLS estimates can be observed with regard to the relationship between foreign exchange rates and market returns where GARCH $(1,1)$ model also specifies a positive association between GBP and stock market returns while a negative association with other two currencies. Moreover, the results further reveal that the magnitude of the coefficients are high for USD and EUR compared to GBP indicating that those currencies are having a relatively strong link with the stock market returns compared to GBP.

The results further show that in the conditional variance equation the intercept term is positive and statistically significant which indicates that there is significant timeinvariant component in the return generating process. Furthermore, the both $\mathrm{ARCH}$ and $\mathrm{GARCH}$ parameters are satisfying the non-negativity condition while both parameters are significant at $1 \%$ significant level. As per results depicted in Table 5, it is evident that the GARCH parameter is significantly greater than the ARCH term illustrating that the volatility of stock returns are more sensitive to its own lagged values than the to its new surprises. Consequently, it would be stated that the effects of previous period's forecast 


\section{International Journal of Science and Research (IJSR) \\ ISSN (Online): 2319-7064 \\ Index Copernicus Value (2013): 6.14 | Impact Factor (2014): 5.611}

variance is more persistent. In addition to that, the summation of GARCH and ARCH parameters closer to unity indicates that the shocks to the ASPI stock returns have highly persistent effects and the response to volatility decays at a slower rate where the findings are in accordance with the findings of Jegajeevan (2012).

Table 5: Estimation of returns

Dependent Variable: RETURN

\begin{tabular}{|c|c|c|c|c|}
\hline \multicolumn{5}{|c|}{ Dependent Variable: RETURN } \\
\hline \multicolumn{5}{|c|}{ Method: ML - ARCH (Marquardt) - Normal distribution } \\
\hline GARCH $=$ C(5) + C(6)*RESID(-1)^2 + C(7)*GARCH(-1) \\
\hline Variable & Coefficient & Std. Error & z-Statistic & Prob. \\
\hline C & 0.00044 & 0.000155 & 2.848222 & 0.0044 \\
\hline USD & -0.11098 & 0.097424 & -1.13913 & 0.2547 \\
\hline GBP & 0.108369 & 0.049867 & 2.173151 & 0.0298 \\
\hline EUR & -0.11265 & 0.038412 & -2.93261 & 0.0034 \\
\hline \multicolumn{5}{|c|}{ Variance Equation } \\
\hline C & $1.41 E-06$ & $3.15 E-07$ & 4.462358 & 0.00000 \\
\hline RESID (-1)^2 & 0.161747 & 0.016849 & 9.599732 & 0.00000 \\
\hline GARCH (-1) & 0.826062 & 0.01562 & 52.88561 & 0.00000 \\
\hline
\end{tabular}

\subsection{Estimation of volatility with CARCH $(1,1)$ model}

The Table 6 presents the empirical results of stock return volatility of ASPI in CSE with the inclusion of US dollar, British Pound and Euro volatilities [The exchange rate volatilities of USD, GBP and EUR are separately calculated using GARCH $(1,1)$ model after testing for $\mathrm{ARCH}$ effect where the results are not presented here to preserve the space]. The empirical findings indicate a lower and significant ARCH parameter which denotes a weak support for the presence of last period's shocks on stock market return volatility whereas relatively large and statistically significant GARCH parameter provides strong evidence for the presence of previous surprises. Despite the inclusion of exchange rate volatilities, the sum of $\mathrm{ARCH}$ and $\mathrm{GARCH}$ parameters as a measure of volatility presence is still approximately closer to the previous results. Further it indicates a weak impact on exchange rate volatilities on the stock market return volatilities irrespective of the currency.

The empirical findings of Table 6 demonstrate that the VolEUR which measures the effect of Euro rate volatility found to be positive and statistically significant with the

Table 6: Volatility estimates

Dependent Variable: RETURN

\begin{tabular}{|c|c|c|c|c|}
\hline \multicolumn{5}{|c|}{ Dependent Variable: RETURN } \\
\hline \multicolumn{5}{|c|}{ Method: ML - ARCH (Marquardt) - Normal distribution } \\
\hline \multicolumn{5}{|c|}{$\begin{array}{c}\text { GARCH }=\mathrm{C}(2)+\mathrm{C}(3) * \mathrm{RESID}(-1)^{\wedge} 2+\mathrm{C}(4) * \mathrm{GARCH}(-1)+ \\
\mathrm{C}(5) * \mathrm{VOLUSD}+\mathrm{C}(6) * \mathrm{VOLGBP}+\mathrm{C}(7) * \mathrm{VOLEUR}\end{array}$} \\
\hline Variable & Coefficient & Std. Error & z-Statistic & Prob. \\
\hline $\mathrm{C}$ & 0.000484 & 0.00016 & 3.020806 & 0.0025 \\
\hline \multicolumn{5}{|c|}{ Variance Equation } \\
\hline $\mathrm{C}$ & $1.14 \mathrm{E}-06$ & $4.43 \mathrm{E}-07$ & 2.569105 & 0.0102 \\
\hline $\operatorname{RESID}(-1)^{\wedge} 2$ & 0.149846 & 0.01592 & 9.412467 & 0.00000 \\
\hline GARCH(-1) & 0.819472 & 0.016634 & 49.26357 & 0.00000 \\
\hline VOLUSD & -0.02735 & 0.014787 & -1.84982 & 0.0643 \\
\hline VOLGBP & -0.05296 & 0.040158 & -1.31882 & 0.1872 \\
\hline VOLEUR & 0.106066 & \begin{tabular}{|l|}
0.025637 \\
\end{tabular} & 4.137165 & 0.00000 \\
\hline
\end{tabular}

stock market return volatility. This synthesizes that when LKR/EUR rate becomes more volatile it will lead to increase in volatility of stock returns of ASPI. Through the globalization as well as open market economic policies, Sri
Lankan capital market has become a potential destination for foreign investors to park their investments where it has ultimately created a severe exposure to the foreign currency risk. Since, as an emerging market economy Sri Lanka still lacks a highly developed market for hedging instruments to mitigate potential exchange rate risks exposures where this can be a potential reason behind the positive association between Euro rate volatility and stock market return volatility. Similar positive relationship between exchange rate and stock market return volatilities are reported by Aggarwal (1981), and Ajayi and Mougoue (1996).Moreover, the empirical results further reveal that volatilities of USD and GBP are negatively influenced on the stock return volatilities while these foreign currency volatilities are found to be insignificant at $95 \%$ confidence level. Further, the magnitude of the negative volatility of USD is lower to that of the GBP volatility towards the stock return volatilities. As Karoui (2006) depicted, emerging market countries are attempting to adjust their currencies around certain powerful global currencies such as US dollars, by adopting free floating rates or managed floating exchange rates so that fluctuations in exchange rates in such currencies become too small compared to others. Thus, it manifests that when the exchange rates become less volatile it will lead to an increase in the volatility in the stock returns of ASPI. Further, Ajayi and Mougoue (1996), Sekman (2011), and Olugbenga (2012) reported similar negative association between exchange rate volatility and stock market return volatility.

\subsection{Diagnostic Tests}

As Gujarati (2004) argued diagnostic tests should be performed in order to determine the suitability and the reliability of the selected model where this study employs correlogram of squared residual test, and the heteroscedasticity test as diagnostic tests. The estimated results of the correlogram of squared residual test are presented in the Table 7 where it demonstrates that all Q statistics at all lags under normal GARCH model are insignificant indicating that there is no significant serial correlation among the residuals.

Table 7: Correlogram of squared residual test

\begin{tabular}{|c|c|c|c|c|}
\hline & AC & PAC & Q-Stat & Prob \\
\hline 1 & 0.036 & 0.036 & 1.8548 & 0.173 \\
\hline 2 & -0.004 & -0.006 & 1.8814 & 0.39 \\
\hline 3 & -0.03 & -0.03 & 3.2117 & 0.36 \\
\hline 4 & -0.026 & -0.023 & 4.1591 & 0.385 \\
\hline 5 & -0.009 & -0.008 & 4.2898 & 0.508 \\
\hline 6 & -0.003 & -0.004 & 4.3037 & 0.636 \\
\hline 7 & -0.014 & -0.016 & 4.6086 & 0.708 \\
\hline 8 & -0.005 & -0.005 & 4.6387 & 0.795 \\
\hline 9 & 0.036 & 0.036 & 6.5348 & 0.685 \\
\hline 10 & -0.025 & -0.029 & 7.4414 & 0.683 \\
\hline 11 & -0.017 & -0.015 & 7.8387 & 0.728 \\
\hline 12 & 0.012 & 0.015 & 8.044 & 0.782 \\
\hline 13 & 0.012 & 0.011 & 8.2421 & 0.827 \\
\hline 14 & 0.019 & 0.017 & 8.773 & 0.845 \\
\hline 15 & -0.033 & -0.035 & 10.379 & 0.795 \\
\hline 16 & 0.001 & 0.006 & 10.382 & 0.846 \\
\hline 17 & 0.029 & 0.03 & 11.625 & 0.822 \\
\hline 18 & -0.027 & -0.033 & 12.714 & 0.808 \\
\hline 19 & -0.027 & -0.024 & 13.806 & 0.795 \\
\hline 20 & -0.024 & -0.02 & 14.62 & 0.798 \\
\hline
\end{tabular}




\section{International Journal of Science and Research (IJSR) \\ ISSN (Online): 2319-7064}

Index Copernicus Value (2013): 6.14 | Impact Factor (2014): 5.611

On the other hand, the results of the heteroscedasticity test are depicted in Table 8 where the $\mathrm{p}$ value of the Obs*Rsquared in not significant which indicates the non-existence of $\mathrm{ARCH}$ effect.

Table 8:Heteroscedasticity test; ARCH

\begin{tabular}{|c|c|c|c|}
\hline \multicolumn{4}{|c|}{ Heteroskedasticity Test: ARCH } \\
\hline F-statistic & 1.849708 & Prob. F(1,1440) & 0.1740 \\
\hline Obs*R-squared & 1.849901 & Prob. Chi-Square(1) & 0.1738 \\
\hline
\end{tabular}

\section{Conclusion}

Investigation of the impact of exchange rate volatility on the stock market return volatility has become immensely important as a consequence of various changes occurred in the global business and financial arena in the recent years. Thus, this study examines the effects of exchange rate volatilities on stock market return volatilities by using both OLS and GARCH estimation models. However, the GARCH model provides more effective and reliable coefficient estimates for the parameters of exchange rates and stock return volatilities as the presence of residual autocorrelation in the OLS model.

The empirical findings of the study suggest that in overall there is a weak impact of exchange rate volatility on stock market return volatility. However, the results further demonstrate that the volatility of Euro exchange rate has a positive and significant effect on the volatility of ASPI returns whilst volatilities of USD and GBP are found to be negative and insignificant. In addition to that, the overall finding of the study seem to be more robust for an emerging financial market such as Sri Lanka, which does not have a well-developed derivative market to provide more opportunities in order to mitigate the exposure to the foreign exchange risks.

The empirical findings of this paper provides valuable insights for local as well as foreign investors regarding their equity investments while the findings are also appealing to the policy makers in devising monetary policies. Thus, these findings provide signals to both local and foreign investors in selection of their equity investments as stock market returns prone to fluctuate against the foreign exchange rate movements. On the other hand, policy makers should also give due consideration on foreign exchange rate policy when devising the monetary policies as the development of the capital market is very much crucial for a sound economic and financial system as well as for a better economic growth.

\section{References}

[1] Adjasi, C.K.D. \& Biekpe, B.N., "Stock Market Returns and Exchange Rate Dynamics in Selected African Countries: A bivariate analysis". The African Finance Journal, 2005.

[2] Adler, M. \& Dumas, B., "International portfolio choice and corporation finance: A synthesis". Journal of Finance, XXXVIII, pp.925-985, 1983.

[3] Aggarwal, R., "Exchange Rates and Stock Prices: A Study of the US Capital Markets under Floating Rates".
Akron Business and Economic Review, XXII, pp.7-12, 1981.

[4] Agrawal, G., Srivastav, A.K. \& Srivastava, A., "A Study of Exchange Rates Movement and Stock Market Volatility". International Journal of Business and Management, V (12), pp.62-73, 2010.

[5] Ajayi, R.A. \& Mougoue, M., "On the dynamic relation between stock prices and Exchange Rates. Journal of Financial Research", XIX, pp.193-207, 1996.

[6] Alam, M.U.G.S. \& Taufique, R.K., "The Relationships between Exchange Rates and Stock Prices: Empirical Investigation from Johannesburg Stock Exchange". Inventi Rapid: Emerging Economics, III, 2011.

[7] Bollerslev, T., "Generalized autoregressive conditional heteroscedasticity". Journal of Econometrics, XXXI, pp.307-327, 1986.

[8] Branson, W.H. \& Henderson, D.W., "The specification and influence of assets". in Jones, R..W.. \& Kenen, P..B.. Handbook of International Economics, 2. Elsevier, 1985.

[9] Frankel, J., Monetary and portfolio-balance models of exchange rate. MIT Press. pp.84-114, 1983.

[10] Gujarati, D., Basic Econometrics. 4th ed. McGraw-Hill Education, 2004.

[11] Jegajeevan, S., "Return Volatility and Asymmetric News Effect in Sri Lankan Stock market". Staff StudiesCentral Bank of Sri Lanka, XL, 2012.

[12] Jorion, P.," The pricing of exchange rate risk in the stock market". Journal of Financial and Quantitative Analysis, LXIV, pp.363-376, 1991.

[13] Joseph, N., "Modelling the impacts of interest rate and exchange rate changes on UK Stock Returns". Derivatives Use, Trading \& Regulation, VII (4), pp.306323, 2002.

[14] Karoui, A., "The correlation between FX rate volatility and stock exchange returns volatility: An emerging markets overview". SSRN e-Library, 2006.

[15] Karunanayake, I., Valadkhani, A. \& O’Brien, M., "Modelling Australian Stock Market Volatility:A Multivariate GARCH Approach". working paper. Research Online, 2009.

[16]Kim, K., "Dollar Exchange Rate and Stock Price: Evidence from Multivariate Cointegration and Error Correction model". Review of Financial Economics, XXII, pp. 301-313, 2003.

[17] Levi, M., "Exchange rates and the valuation of firms". in Amihud, Y. \& Levich, R.M. Exchange Rates and Corporate Performance. New York, 1994.

[18] Marston, R., "The effects of industrial structure on economic exposure". working paper. University of Pennsylvania, 1998.

[19] Maysami, R. \& Koh, T., "A Vector Error Correction Model of the Singapore Stock Market". International Review of Economics and Finance, IX (1), pp.79-96, 2000.

[20] Mishra K., A., "Stock market and foreign Exchange market in India. Are they related?"South Asia Economic Journal, 5(II) 2004.

[21] Morales, L.N., "Volatility Spillovers between Equity and Currency Markets: Evidence from Major Latin American Countries". Cuadernos de Economía, XLV, pp.185-215, 2008. 


\section{International Journal of Science and Research (IJSR) \\ ISSN (Online): 2319-7064}

Index Copernicus Value (2013): 6.14 | Impact Factor (2014): 5.611

[22] Muktadir-Al-Mukit, D., "Effects of Interest Rate and Exchange Rate on Volatility of Market Index at Dhaka Stock Exchange". Journal of Business and Technology (Dhaka), VII (2), 2012.

[23]Najang \& Seifert, B., "Volatility of exchange rates, interest rates, and stock returns". Journal of Multinational Financial Management, II, pp.1-19, 1992.

[24] Olugbenga, A.A., "Exchange Rate Volatility and Stock Market Behaviour: The Nigerian Experience". Research Journal of Finance and Accounting, III (3), pp.88-96, 2012.

[25] Parkinson, J.M., "The EMH and the CAPM on the Nairobi Stock Exchange". East African Economic Review, XIII, pp.105-110, 1987.

[26] Peiris, T.U.I. \& Peiris, T.S.G.,"International conference on Business and Information. Measuring Stock Market Volatility in an Emerging Economy"., In proceedings of theInternational conference on Business and Information, 2011.

[27] Sekmen, F., "Exchange rate volatility and stock returns for the U.S."African Journal of Business Management, V, pp.965-964, 2011.

[28] Sercu, P., "A generalisation of the international asset pricing model". French Finance Association Journal , I, pp.91-135, 1980.

[29] Shapiro, A., "Exchange rate changes, inflation, and the value of the multinational corporation". Journal of Finance, XXX, pp.485-502, 1975.

[30] Solnik, B., "Using financial prices to test exchange rate models- A note". Journal of Finance, 42, pp.41-49, 1987.

[31] Subair, K., "Exchange Rate Volatility and the Stock Market: The Nigerian Experience". Kwara State University, Malete, Nigeria, 2010. 